\title{
Environment discomfort and ability to sustain the performance level during life time under the sub-tropical conditions in imported Holstein Friesian young cows
}

\author{
IBRAHIM FAYEZ MAHMOUD MARAI, ABEL-HALIM ALI EL-DARAWANY, ABDEL-MAGEED \\ SAYED NASR and MOHAMED ABDEL-HAMID SHEHATA
}

Department of Animal Production, Faculty of Agriculture, Zagazig University, Zagazig, Egypt

\begin{abstract}
In the present study, the Holstein Friesians were imported from Germany to the sub-tropical environment in Jordan as pregnant (between 5 and 7 months) heifers. The study included some performance traits as affected by season of the year, parity and classes of each of milk yield, lactation period and days open.

The results indicated that the animals were exposed to severe heat stress during summer and to mild climate (without heat stress) during autumn and winter. Days open, lactation period and calving interval values were higher $(P<0.05)$ in summer than in autumn The estimated average deviations percentage occurred as a result to the inadequate conditions was 37.8 for imported young cows, when considering that the optimum comfort environmental temperature for Holstein cattle as $10^{\circ} \mathrm{C}$.

Effects of parity were significant $(P<0.001$ or 0.01 ) on days open, number of inseminations per conception, milk yield and calving interval. The estimated values were higher $(P<0.05)$ in the second parity than in the other parities. Average deviations in the traits in different parities, relatively to the values of the same traits in the first parity, was estimated as $10.33 \%$.

When studying the effects of some trait classes, it was found that days open and number of services per conception increased $(P<0.001)$ with the increase in classes of milk yield, dry period and calving interval also increased $(P<0.001)$ with the increase in classes of lactation period, and lactation increased $(P<0.001)$ with the increase in classes of days open.

The results may indicate that deterioration of the newly imported Holstein cow traits under the sub-tropical environment, a state of reversal to origin.
\end{abstract}

Keywords: Holstein Friesian cows, performance traits, sustainable ability index, discomfort index, temperature-humidity index, sub-tropical conditions

\section{Zusammenfassung}

\section{Umweltbedingte Erschwernisse durch subtropische Bedingungen sowie ihr Einfluss auf die Lebensleistung von importierten Holstein Friesian Jungkühen}

Es wurden verschiedene Einflussgrößen auf Milch- und Reproduktionsleistungen von 380 aus Deutschland importierten 5-7 Monate tragenden Färsen untersucht. Die Tiere waren erschwerten klimatischen Bedingungen während einzelner Jahreszeiten in Jordanien ausgesetzt. Zwischentragezeit, Laktationsdauer und Kalbeintervall waren im Sommer 
signifikant länger als vor allem im Herbst. Dieser negative Sommereinfluss galt auch für die Anzahl der Besamungen je Trächtigkeit. Die Durchschnittswerte für die Temperatur lagen z. B. im Winter bei 8,8 dagegen im Sommer bei $25,2^{\circ} \mathrm{C}$, für die relative Feuchtigkeit bei 77,9 bzw. 49,3\% und für die effektive Temperatur (THI) bei 9,2 bzw. 23,5. Signifikante Einflüsse der Laktationnummer fanden sich bei der Zwischentragezeit, der Anzahl Besamungen je Trächtigkeit, dem Milchertrag und Kalbeabstand. Die ermittelten Werte waren in der zweiten Laktation signifikant höher als bei den anderen Laktationen. Die durchschnittlichen Abweichungen bei den unterschiedlichen Laktationsnummern lagen, verglichen mit den Merkmalswerten der ersten Laktation, bei 10,33\%. Mit steigendem Milchertrag ergab sich ein signifikanter Anstieg der Werte für die Zwischentragezeit, die Besamungen je Trächtigkeit, der Trockenzeit und des Kalbeabstandes. Die Ergebnisse zeigen dass bei frisch importieren Holsteinkühen die erzielten Leistungen unter subtropischen Bedingungen von den original erzielten Ergebnissen besonders im Sommer negativ abweichen.

Schlüsselwörter: Holstein Friesian, Kuh, Leistungsmerkmale, discomfort index, sustainable ability index, effektive Temperatur (THI), subtropische Bedingungen

\section{Introduction}

Temperate-type dairy breeds are usually imported to developing countries for their high efficiency in milk and/or meat production.

In the sub-tropical Middle East countries, many batches of temperate breeds of cattle have been introduced, either from Holland and Germany (Friesians) or from the USA (Holstein Friesian), during the last decades. Such animals suffer from the hot climate in the new localities (HABEEB et al. 1992, 1996, FARGHALY et al. 1997, MARAl et al. 1999, KHATTAB et al 2005).

Particularly, temperate-type Holstein cattle have a thermal comfort zone for milk production within the range -5 to $20^{\circ} \mathrm{C}$ with optimal production at $10^{\circ} \mathrm{C}$ and a critical range of $21-27^{\circ} \mathrm{C}$ after which milk production declines steeply. The butterfat content of milk of temperate cows declines slowly until the ambient temperature reaches $29^{\circ} \mathrm{C}$ and then rises. This is presumably due to the fact that above $29^{\circ} \mathrm{C}$, the decline in milk production is more rapid than the decline in the percentage of butterfat. However, the comfort zone is different and varies with age. Most very young livestock require higher ambient temperature immediately after birth than they do at late stages of growth (PAYNE 1990).

The thermal comfort zone is the ambient temperature range within which the metabolic rate of the animal is independent of environmental temperature, and any value below or above that range may create discomfort to the animal.

Occurrence of inadequacies or constrains in environment, nutrition, management and/ or disease, cause considerable discomfort to the animals, that leads to inefficiencies in production and physically restricting their performance.

The present study aimed to throw some light on performance of the imported young Holstein Friesian as affected by the sub-tropical conditions, in Jordan. The study included estimation of the environment discomfort and the ability of the animals to sustain their level of performance traits during their life under such conditions. 


\section{Materials and methods}

The study was carried out in the Department of Animal Production, Faculty of Agriculture, Zagazig University, Zagazig, Egypt, on records of Holstein Friesian cows. The animals were located in a farm, El-Zarka city $\left(30^{\circ} \mathrm{N}\right)$ north to Amman, Jordan, during the year 2000.

The number of 955 records of Holstein Friesian cows were collected by Alpro System, during 1st , 2nd, 3rd or 4th lactation. Number of animals used in the study was 380 . The animals were imported from Germany as pregnant (between 5 and 7 months) heifers. All animals were healthy and clinically free of external and internal parasites and were kept, maintained and treated in adherence to accepted standards for the humane treatment of animals.

Animals feed requirements were provided according to the level of milk production (NRC 1978). The feeding system used was total mixed rations (TMR). Amounts of concentrates fed/ each ten capita were $180 \mathrm{~kg}$ wheat bran, $200 \mathrm{~kg}$ corn cracked, $400 \mathrm{~kg}$ barley, $200 \mathrm{~kg}$ soybean meal, $10 \mathrm{~kg}$ limestone and $10 \mathrm{~kg}$ sodium chloride. Feeding levels of milk yield was as shown in Table 1.

The animals were housed in open sheds situated in yards. Every yard was surrounded by a fence made of three iron tubes fixed in a horizontal position. Each tube was 0.12 inch in diameter, with $50 \mathrm{~cm}$ in between (total height 1.5 meters). In each yard, the shaded part represented one third of the whole area of the yard. Yards were designed to allow free way to the milking parlour, which is located in a middle position among yards. Ambient air temperature and relative humidity were recorded in the shaded parts of the yards (Table 2).

Table 1

Ingredients and the feeding per levels of milk yield

Futterzusammensetzung und Futtermenge nach Milchertrag

\begin{tabular}{lccc}
\hline Ingredients & & Levels of milk yield & $<-8 \mathrm{~kg}$ \\
\hline Hay & $8-11 \mathrm{~kg}$ & $6-8 \mathrm{~kg}$ & 1 \\
Alfalfa & 3 & 4 & 2 \\
Silage & 7 & 8 & 6 \\
Concentrates & 8 & 13 & 8 \\
Wheat straw & 15 & 0 & 3 \\
\hline
\end{tabular}

Cows were machine milked three times a day (at 4:00, 12:00 and 20:00 h). A double herringbone parlour containing 64 units, was used.

Table 2

Means of ambient temperature $\left({ }^{\circ} \mathrm{C}\right)$, relative humidity $(\mathrm{RH} \%)$ and temperature-humidity index (THI) during the seasons of the year in Jordan

Durchschnittswerte für Temperatur $\left({ }^{\circ} \mathrm{C}\right)$, relative Feuschtigkeit (RH \%) und effektive Temperatur (THI) nach Jahreszeiten in Jordanien

\begin{tabular}{lccr}
\hline Seasons & ${ }^{\circ} \mathrm{C}$ & $\mathrm{RH} \%$ & $\mathrm{THI}$ \\
\hline Winter & 8.8 & 77.9 & 9.2 \\
Summer & 25.2 & 49.3 & 23.5 \\
Autumn & 18.4 & 57.3 & 17.9 \\
\hline
\end{tabular}


The study included cow traits along with some factors affecting. The traits were days open, number of inseminations per conception, milk yield, lactation period, dry period and calving interval. The temperature-humidity index (THI) was estimated according to MARAl et al. (2009) as follows:

$$
T H I=d b^{\circ} \mathrm{C}-\left[(0.31-0.31 R H)\left(d b^{\circ} \mathrm{C}-14.4\right)\right]
$$

where $d b^{\circ} \mathrm{C}$ is the dry bulb temperature in Celsius and $R H$ is the $R H \%$ (relative humidity percentage)/100. The $T H /$ values were then classified as follows: Less than 22.2 is the absence of heat stress, 22.2 to $<23.3$ is the moderate heat stress, 23.3 to $<25.6$ is the severe heat stress and 25.6 and more is the very severe heat stress.

Absolute value of discomfort index (DI) was estimated as shown below:

$D I=[\{$ Observed value - Lower or upper limit of optimum range (regardless the minus or plus signs)\} / $\{$ the same Lower or upper limit of optimum range $\}] \times 100$

The ability of the animal to sustain its level of performance traits under the environmental conditions was measured by the sustainable ability index (SAI), during the life of the animal. This is carried out by: estimation of the average of deviations in each of the traits in the different parities (regardless the minus or plus signs), relatively to the value of the same trait in the first parity. Then this last value is used to detect SAI as 1 - the average relative deviations in all the traits studied. However, it should be remembered that the accuracy of DI or sustainable ability index (SAI), increases with the increase in data detailed specifications, in this respect (MARAl et al. under publication).

Statistically, means were estimated using the factorial design analysis according to SNEDECOR and COCKRAN (1994). Significance of the differences were tested by Duncan's multiple range test (DUNCAN 1955). All statistical analyses were carried out by SAS Program (1993). Statistical analysis was carried out according to the models:

Days open:

$$
Y_{i j k l m n}=\mu+P_{i}+C S_{j}+C F S_{k}+C T_{1}+C M Y_{m}+e_{i j k l m n}
$$

where $\mu$ is the overall mean, $P_{i}$ is the fixed effect of $i$-th parity $(1, \ldots 4), C S_{j}$ is the fixed effect of $j$-th season of calving $(1, \ldots 4), C_{k}$ is the fixed effect of $k$-th sex of calf (female, male and none), $C T$, is the fixed effect of $I$-th calving type (single, twins and none), $C M Y_{m}$ is the fixed tof $m$-th classes of milk yield ( $<6000$ to $>12000 \mathrm{~kg}$ milk) and $e_{i j k l m n}$ is the random error.

Number of services per conception:

$$
Y_{i j k l}=\mu+P_{i}+I N S_{j}+C M Y_{k}+e_{i j k l}
$$

where $\mu$ is the overall mean, $P_{i}$ is the fixed effect of $i$-th parity $(1, \ldots 4), I N S_{j}$ is the fixed effect of $j$-th season of insemination $(1, \ldots 4), C M Y_{k}$ is the fixed effect of $k$-th classes of milk yield $(1, \ldots 3)$ and $e_{i j k l}$ is the random error.

Milk yield:

$$
Y_{i j k l m n}=\mu+P_{i}+C S_{j}+C F S_{k}+C T_{1}+C L P_{m}+e_{i j k l m n}
$$

where $\mu$ is the overall mean, $P_{i}$ is the fixed effect of $i$-th parity $(1, \ldots 4), C S$ is the fixed effect of $j$-th season of calving $(1, \ldots 4), C F S_{k}$ is the fixed effect of $k$-th sex of calf $(1, \ldots 3), C T$, is the fixed 
effect of $l$-th calving type $(1, \ldots 3), C L P_{m}$ is the fixed $t$ of $m$-th classes of lactation period $(1, \ldots 3)$ and $e_{i j k m n}$ is the random error.

lactation period:

$$
Y_{i j k m n}=\mu+P_{i}+C S_{j}+C D O_{k}+C F S_{1}+C T_{m}+e_{i j k m n}
$$

where $\mu$ is the overall mean, $P_{i}$ is the fixed effect of $i$-th parity $(1, \ldots 4), C S_{i}$ is the fixed effect of $j$-th season of calving $(1, \ldots 4), C D O_{k}$ is the fixed effect of classes of days open $(1, \ldots 5), C F S$, is the fixed effect of $l$-th sex of calf $(1, \ldots 3), C T_{m}$ is the fixed effect of $m$-th calving type $(1, \ldots 3)$ and $e_{i j k m n}$ is the random error.

Dry period:

$$
Y_{i j k l}=\mu+P_{i}+C M Y_{j}+C L P_{k}+e_{i j k l}
$$

where $\mu$ is the overall mean, $P_{i}$ is the fixed effect of $i$-th parity $(1, \ldots 4), C S$ is the fixed effect of $j$-th season of calving $(1, \ldots 4), C M Y_{k}$ is the fixed effect of $k$-th classes of milk yield $(1, \ldots 3), C L P_{k}$ is the fixed effect of $k$-th classes of lactation period $(1, \ldots 3)$ and $e_{i j k l}$ is the random error.

Calving interval:

$$
Y_{i j k l m n o}=\mu+P_{i}+C S_{j}+C F S_{k}+C T_{1}+P T_{m}+C L P_{n}+e_{i j k l m n o}
$$

where $\mu$ is the overall mean, $P_{i}$ is the fixed effect of $i$-th parity $(1, \ldots 4), C S$ is the fixed effect of $j$-th season of calving $(1, \ldots 4), C F S_{k}$ is the fixed effect of $k$-th sex of calf $(1, \ldots 3), C T$, is the fixed effect of $l$-th type of calving $(1, \ldots 3), P T_{m}$ is the fixed effect of $m$-th pregnant type $(1, \ldots 3), C L P_{n}$ is the fixed $t$ of $m$-th classes of lactation period $(1, \ldots 3)$ and $e_{i j k l m n o}$ is the random error.

\section{Results}

In the present study, three indices were estimated: The temperature-humidity index (THI), discomfort index (DI) and sustainable ability index (SAI). Each Index showed something different than the other, but all are related to the environmental conditions. The THI showed the level of heat stress in the different seasons. The DI showed percentage of the deviation occurred as a result to inadequate conditions. The SAI measured the ability of the animal to sustain its level of performance traits under the new environmental conditions by estimation of the average deviation in each of the traits in the different parities, relatively to the value of the same trait in the first parity, The deviations estimated in DI and SAI were employed regardless the minus or plus signs.

The estimated THI values were 9.2 during winter, 17.9 during autumn and 23.5 during summer, indicating absence of heat stress during winter and autumn and exposure to severe heat stress during summer (Table 2).

Season of calving affected significantly $(P<0.001)$ days open, lactation period and calving interval (Tables $3,6,8)$. Summer surpassed $(P<0.05)$ autumn and winter seasons in the estimated values. The discomfort index (DI) value was estimated as $62.2 \%$ for imported young cows, when considering that the optimum comfort environmental temperature for Holstein cattle as $10^{\circ} \mathrm{C}$ (PAYNE 1990). The estimated average deviations percentage occurred as a result to inadequate conditions was 37.8 for the same imported young cows. 
Effects of parity were significant $(P<0.001$ or 0.01$)$ on days open, number of inseminations per conception, milk yield and calving interval (Tables 3-8). The estimated values were higher $(P<0.05)$ in the second parity than in the other parities.

The estimated sustainable ability index of the performance traits during the life time of the imported young cows (as average of deviations in each of the traits in the different parities, relatively to the value of the same trait in the first parity) was estimated as $89.67 \%$. The average relative deviations in the studied traits between the different parities and first parity was estimated as $10.33 \%$.

When studying the effects of trait classes, it was found that days open and number of services per conception increased $(P<0.001)$ with the increase in classes of milk yield. Milk yield, dry period and calving interval also increased $(P<0.001)$ with the increase in classes of lactation period, and lactation increased $(P<0.001)$ with the increase in classes of days open (Tables 3-8)

Table 3

Days open (Days) of Holstein Friesian cows as affected by parity, season of calving and classes of milk yield, in Jordan

Zwischentragezeit nach Laktationnummer, Kalbesaison, Milchertrag

\begin{tabular}{|c|c|c|}
\hline Items & No. of animals & Days open (Days) \\
\hline \multicolumn{3}{|l|}{ Season of calving } \\
\hline Winter & 87 & $134.91^{b} \pm 10.67$ \\
\hline Summer & 111 & $157.74^{\mathrm{a}} \pm 4.40$ \\
\hline Autumn & 142 & $103.29^{b} \pm 5.18$ \\
\hline Significance & & $* * *$ \\
\hline \multicolumn{3}{|l|}{ Parity } \\
\hline 1th & 36 & $135.47^{b} \pm 15.46$ \\
\hline 2nd & 85 & $162.99^{\mathrm{a}} \pm 9.70$ \\
\hline $3 r d$ & 162 & $139.02^{\mathrm{b}} \pm 5.70$ \\
\hline 4th & 97 & $106.73^{c} \pm 4.60$ \\
\hline Significance & & $* * *$ \\
\hline \multicolumn{3}{|c|}{ Classes of milk yield } \\
\hline$<6000 \mathrm{~kg}$ & 77 & $83.35^{c} \pm 3.03$ \\
\hline $6000-12000 \mathrm{~kg}$ & 284 & $138.89^{b} \pm 3.93$ \\
\hline$>12000 \mathrm{~kg}$ & 19 & $302.2^{\mathrm{a}} \pm 19.52$ \\
\hline Significance & & $* * *$ \\
\hline
\end{tabular}

*** $P<0.001$, Means within each classification bearing different letters, differed significantly $(P<0.05)$ 
Table 4

Number of inseminations per conception of Holstein Friesian cows as affected by parity, season of insemination and classes of milk yield, in Jordan

Anzahl Besamungen nach Laktationsnummer, Saison, Milchertrag

\begin{tabular}{|c|c|c|}
\hline Items & No. of animals & Number of services \\
\hline \multicolumn{3}{|l|}{ Parity } \\
\hline 1 & 36 & $2.58^{b} \pm 0.43$ \\
\hline 2 & 85 & $3.35^{\mathrm{a}} \pm 0.27$ \\
\hline 3 & 162 & $2.97^{a b} \pm 0.15$ \\
\hline 4 & 97 & $2.23^{c} \pm 0.14$ \\
\hline Significance & & $* *$ \\
\hline \multicolumn{3}{|c|}{ Season of insemination } \\
\hline Winter & 199 & $2.59^{b} \pm 0.14$ \\
\hline Summer & 37 & $3.81^{\mathrm{a}} \pm 0.37$ \\
\hline Autumn & 18 & $2.83^{b} \pm 0.56$ \\
\hline Significance & & $* *$ \\
\hline \multicolumn{3}{|c|}{ Classes of milk yield } \\
\hline$<6000 \mathrm{~kg}$ & 77 & $1.83^{c} \pm 0.15$ \\
\hline $6000-12000 \mathrm{~kg}$ & 284 & $2.90^{\mathrm{b}} \pm 0.11$ \\
\hline$>12000 \mathrm{~kg}$ & 19 & $5.84^{\mathrm{a}} \pm 0.72$ \\
\hline Significance & & $* * *$ \\
\hline
\end{tabular}

${ }^{* * *} P<0.001$ and ${ }^{*} P<0.01$, means within each classification bearing different letters, differed significantly $(P<0.05)$

Table 5

Milk yield (kg) of Holstein Friesian cows as affected by parity, season of calving and classes of lactation period, in Jordan

Milchertrag nach Laktationsnummer, Kalbesaison, Laktationsdauer

\begin{tabular}{lcc}
\hline Items & No. of animals & Milk yield \\
\hline Season of calving & & \\
$\quad$ Winter & 87 & $7455.37 \pm 291.29$ \\
Summer & 111 & $8445.12 \pm 181.48$ \\
Autumn & 142 & $7362.77 \pm 167.89$ \\
$\quad$ Significance & & not significant \\
Parity & 36 & \\
1 & 85 & $6899.94^{\mathrm{c}} \pm 452.25$ \\
2 & 162 & $8245.20^{\mathrm{a}} \pm 302.94$ \\
3 & 97 & $7148.85^{\mathrm{a}} \pm 161.52$ \\
4 & & $7397.59^{\mathrm{b}} \pm 195.50$ \\
Significance & & $* * *$ \\
Classes of lactation period & 116 & $6116.68^{\mathrm{c}} \pm 148.96$ \\
$<300$ days & 240 & $8314.52^{\mathrm{b}} \pm 126.23$ \\
$300-500$ days & 24 & $11745.79^{\mathrm{a}} \pm 315.19$ \\
$>500$ days & & $* * *$ \\
Significance & & \\
$* * * P<0.001, * * P<0.01$, means within each classification bearing different letters, differ significantly $(P<0.05)$
\end{tabular}


Table 6

Lactation period (days) of Holstein Friesian cows as affected by parity, season of calving and classes of days open, in Jordan

Laktationsdauer nach Laktationsnummer, Kalbesaison, Zwischentragezeit

\begin{tabular}{lcc}
\hline Items & No. of animals & Lactation period \\
\hline Season of calving & & \\
$\quad$ Winter & 87 & $347.38^{\mathrm{b}} \pm 11.12$ \\
Summer & 111 & $377.41^{\mathrm{a}} \pm 4.50$ \\
Autumn & 142 & $319.85^{\mathrm{c}} \pm 5.18$ \\
Significance & & $* * *$ \\
Parity & 36 & $351.11 \pm 15.46$ \\
1 & 85 & $378.04 \pm 10.02$ \\
2 & 162 & $357.49 \pm 5.94$ \\
3 & 97 & $323.45 \pm 4.77$ \\
4 & & not significant \\
Significance & 28 & $265.18^{\mathrm{d}} \pm 2.65$ \\
Classes of days open & 59 & $287.27^{\mathrm{c}} \pm 1.72$ \\
$<60$ days & 83 & $303.63^{\mathrm{c}} \pm 1.26$ \\
$60-81$ days & 38 & $328.08^{\mathrm{b}} \pm 1.91$ \\
$82-103$ days & 172 & $418.72^{\mathrm{a}} \pm 5.29$ \\
$103-124$ days & & $* * * *$ \\
$>124$ days & & \\
Significance & & \\
\hline
\end{tabular}

***P $P 0.001$, means within each classification bearing different letters, differ significantly $(P<0.05)$

Table 7

Dry period (Days) of Holstein Friesian cows as affected by parity and classes of milk yield and lactation period, in Jordan

Trockenzeit nach Laktationsnummer Milchertrag, Laktationsdauer

\begin{tabular}{|c|c|c|}
\hline Items & No. of animals & Dry period \\
\hline \multicolumn{3}{|l|}{ Parity } \\
\hline 1 & 36 & $66.36 \pm 1.58$ \\
\hline 2 & 85 & $66.95 \pm 1.42$ \\
\hline 3 & 162 & $63.54 \pm 0.81$ \\
\hline 4 & 97 & $65.28 \pm 0.97$ \\
\hline Significance & & not significant \\
\hline \multicolumn{3}{|c|}{ Classes of milk yield } \\
\hline$<6000 \mathrm{~kg}$ & 77 & $69.43 \pm 1.34$ \\
\hline $6000-12000 \mathrm{~kg}$ & 284 & $63.73 \pm 0.61$ \\
\hline$>12000 \mathrm{~kg}$ & 19 & $66.37 \pm 2.24$ \\
\hline Significance & & not significant \\
\hline \multicolumn{3}{|c|}{ Classes of lactation period } \\
\hline$<300$ days & 116 & $70.43^{\mathrm{a}} \pm 1.12$ \\
\hline $300-500$ days & 240 & $62.54 b \pm 0.58$ \\
\hline$>500$ days & 24 & $63.58^{\mathrm{b}} \pm 2.42$ \\
\hline Significance & & $* * *$ \\
\hline
\end{tabular}

${ }^{* * *} P<0.001$, means within each classification bearing different letters, differ significantly $(P<0.05)$. 
Table 8

Calving interval (Days) of Holstein Friesian cows as affected by parity, season of calving and classes of lactation period, in Jordan

Kalbeintervall nach Laktationsnummer, Kalbesaison, Laktationsdauer

\begin{tabular}{lcc}
\hline Items & No. of animals & Calving interval \\
\hline Season of calving & & \\
$\quad$ Winter & 87 & $416.92^{\mathrm{b}} \pm 10.67$ \\
Summer & 111 & $439.74^{\mathrm{a}} \pm 4.40$ \\
Autumn & 142 & $385.29^{\mathrm{c}} \pm 5.18$ \\
$\quad$ Significance & & $* * *$ \\
Parity & & \\
1 & 36 & $417.47^{\mathrm{b}} \pm 15.46$ \\
2 & 85 & $444.99^{\mathrm{a}} \pm 9.70$ \\
3 & 162 & $421.02^{\mathrm{b}} \pm 5.70$ \\
4 & 97 & $388.73^{\mathrm{c}} \pm 4.60$ \\
Significance & & $* * *$ \\
Classes of lactation period & & $353.08^{\mathrm{c}} \pm 1.56$ \\
$<300$ days & 116 & $429.31^{\mathrm{b}} \pm 3.28$ \\
$300-500$ days & 240 & $615.58^{\mathrm{a}} \pm 10.14$ \\
$>500$ days & 24 & $* * *$ \\
Significance & & \\
\hline
\end{tabular}

${ }^{* * *} P<0.001,{ }^{* *} P<0.01$, means within each classification bearing different letters, differ significantly $(P<0.05)$

\section{Discussion}

It is well known that any change in environmental conditions than the optimum requirements causes discomfort for the animal. For example, any value below or above the range values of minimum and maximum climatical elements (i.e. in temperature, humidity, wind velocity, rainfall, evaporation and sunshine duration) or in any inadequacy in nutritional level may create discomfort to the animal. In the present study, estimation the measurement of the discomfort index (FORBES 1999) was modified as shown below.

FORBES (1999) considered that Environment discomfort is derived as simple aggregative index during each day of the experimental period. In this respect, observed values of minimum and maximum temperature, humidity, wind velocity, rainfall, evaporation and sunshine duration during each day of the experimental periods were compared with lower or upper limit of their optimum range, i.e. absolute value of the simple aggregate index was derived as

(Observed value-Optimum range/Lower or upper limit of optimum range) $\times 100$

Meanwhile, estimation of the absolute value of discomfort index (DI) in the present study was modified as:

$D I=[\{$ Observed value - Lower or upper limit of optimum range (regardless the minus or plus signs)\} / \{the same Lower or upper limit of the optimum range $\}] \times 100$

where optimum ambient temperature for Holstein was $10^{\circ} \mathrm{C}$ according to PAYNE (1990). In other words, the average deviations due to the observed constraints, e.g. each of climatic inadequacies (temperature, wind velocity, rainfall, evaporation and sunshine duration) and/ 
or nutritional than the lower or upper limit of its optimum range (regardless the minus or plus signs), relatively to the same lower or upper limit of the optimum range, were used to estimate the absolute value of discomfort index (DI). Further, it can be suggested that for more simplicity, lower or upper limit of optimum range of the detailed climatic parameters can be replaced by either a or b of that shown below:

a) Lower or upper limit of optimum ambient temperature range, since the ambient temperature is affected by all the climatic parameters and the changes in all these parameters are reflected on the values of ambient temperature, i.e. the ambient temperature value may represent the final output of such climatic parameters.

b) The temperature-humidity index (THI), i.e. the combined effect of both ambient temperature and relative humidity (LPHSI 1990, MARAl et al. 2009).

Regarding the effect of season of calving, the reproductive traits seemed to deteriorate under the sub-tropical hot conditions, since days open, lactation period and calving interval were higher significantly $(P<0.05)$ in summer than in the other seasons. TAWFIK et al. $(2000)$, ABDEL-GADER et al. (2007) (in Friesians) and TEKERLY and KOCAK (2009) (in Holsteins) reported similar results under hot conditions. BÜLBÜL and ATAMAN (2009) reported that in Holstein cows under sub-tropical environment oestrus rate was higher in summer (oestrus rate: $\mathrm{THI} r=0.43$ ) and light has a stimulative effect on reproductive performance. Temperature up $23^{\circ} \mathrm{C}$ did not cause a suppressive effect and up to $29.4^{\circ} \mathrm{C}$ had an adverse effect on the reproductive performance and oestrus expression (O'CONNOR 1993, quoted at BÜLBÜL and ATAMAN). MARAl et al. (2007b) reported that in rabbits exposure of young pregnant females to severe heat stress under the warm sub-tropical environmental conditions of Egypt, affected negatively most of the maternal traits studied and the effects were more deleterious during the 2 nd half when compared to the 1st half of pregnancy.

The discomfort index (DI) value was estimated as $62.2 \%$, as a result to a value of $37.8 \%$ average deviations caused by the inadequate conditions, under the sub-tropical conditions.

The significant increase $(P<0.001)$ in days open and number of services per conception with the increase in classes of milk yield, and the similar increase $(P<0.001)$ in milk yield, dry period and calving interval with the increase in classes of lactation period, in addition to the increase $(P<0.001)$ in lactation period with the increase in classes of days open, may help in increasing the deteriorative effects on the reproductive traits, under the sub-tropical conditions.

Under thermal stress conditions, depression in feed consumption is the most important reaction to exposure to elevated temperature (MARAI and HABEEB 1998, MARAl et al. 2004). Such phenomenon is due to that environmental temperature stimulates the peripheral thermal receptors to transmit suppressive nerve impulses to the appetite centre in the hypothalamus, causing the decrease in feed consumption, i.e. decrease in dry matter intake. Consequently, fewer substrates become available for enzymatic activities, hormone synthesis and heat production, to help in preventing the rise in body temperature and to better cooling the body. Prolonged heat exposure suppresses the production of hormone releasing factors from the hypothalamic centres causing reductions in pituitary prolactin, somatotropin, thyrotropin and leutinizing hormone, insulin and possibly parathormone. The decrease in the substrates and hormones and the rise in body temperature inhibit the enzymatic activities, which decrease the metabolism and consequently impair growth 
and reproduction (MARAl et al. 2008). These phenomena evidently help in alleviation the heat load in animals. Mineralocorticoids seemed also to decrease due to changes in blood electrolytes. On the other hand, fat and protein catabolism increases due to the increase in catecholamines (lypolytic hormones) and glucocorticoids (proteolytic hormones, but for a few days only), respectively. Such changes increase the surface area per body weight for better heat dissipation (MARAl et al. 2007a).

The increase $(P<0.05)$ in days open, number of inseminations per conception, milk yield and calving interval in the second parity than in the other parities, also may help in intensifying the deteriorative effects on the reproductive traits, under the sub-tropical conditions.

The estimated sustainable ability index of the performance traits during the life time of the imported young cows (as averages of deviations in each of the traits in different parities, relatively to the value of the same traits in the first parity) was estimated as $89.67 \%$. The average relative deviations in the 2-5 parities was estimated as $10.33 \%$. The estimated value of the sustainable ability index value as $89.67 \%$ under the sub-tropical conditions in Jordan, may show that the imported young cows suffered from adaptation problems.

In conclusion the results may indicate that the imported Holstein young cows show a state of reversal to origin, since their earlier ancestors (humpless cattle, Bos taurus) were domesticated of a sub-tropical fauna which was in the Middle East Region at 8000-9000 years ago (PAYNE 1990). This may give an alarm to what is expected in the future for the highly productive temperate breeds, owing to the increase in global temperature as a result of the greenhouse effect. Such results may suggest to screen and breed indigenous animals with better productive level within the hot climate areas and/or to breed highly productive animals better adapted to hot climates.

\section{References}

Abdel-Gader AZA, Ahmed MKA, Musa LMA, Peters KJ (2007) Milk yield and reproductive performance of Friesian cows under Sudan tropical conditions. Arch Tierz 50, 155-64

Bülbül B, Ataman MB (2009) The effect of some seasonal conditions on oestrus occurrence in cows. Arch Tierz 52, 459-65

Duncan DB (1955) Multiple range and multiple F-test. Biometrics 11, 1-42

Farghaly HM, Marai IFM, Gabr HA, Pirchiner F (1997) Changes of stayability, milk and calf production in Friesian in Egyptian environments. Journal of Agriculture in the Tropics and Subtropics 98, 151-62

Forbes JM (1999) Minimal total discomfort as a concept for the control of food intake and selection. Appetite 33,171

Habeeb AA, El-Masry KA, Aboul-Naga Al, Kamal TH (1996) The effect of hot summer climate and level of milk yield on blood biochemistry and circulating thyroid and progesterone hormones in Friesian cows. Arab J Nuclear Sci Appl 29, 161-73

Habeeb AA, Marai IFM, Kamal TH (1992) Heat stress. In: Phillips CJC, Piggins D (eds) Farm Animals and the Environment. CABI Publishing, UK, 27-47

Hill D (1989) Cattle and Buffalo Meat Production in the Tropics (Intermediate tropical agriculture series). Longman International Education, UK

Khattab AS, Atil H, Badawy L (2005) Variances of direct and maternal genetic effects for milk yield and age at first calving in a herd of Friesian cattle in Egypt. Arch Tierz 48, 24-31

LPHSI (1990) Livestock and Poultry Heat Stress Indices Agriculture Engineering Technology Guide. Clemson University, Clemson, SC 29634, USA 
Marai IFM, El-Darawany AA, Abou-Fandoud El, Abdel-Hafez MAM (2004) Reproductive traits and the physiological background of the seasonal variations in Egyptian Suffolk ewes under the conditions of Egypt. Ann Arid Zone 42, 1-9

Marai IFM, El-Darawany A-HA, Ismail E-S A-F, Abdel-Hafez MAM (2009) Reproductive and physiological traits of Egyptian Suffolk rams as effected by selenium dietary supplementation and housing heat radiation effects during winter of the sub-tropical environment of Egypt. Arch Tierz 52, 402-9

Marai IFM, El-Darawany AA, Fadiel A, Abdel-Hafez MAM (2007a) Physiological traits as affected by heat stress in sheep - a review. Small Rumin Res 71, 1-12

Marai IFM, El-Darawany AA, Fadiel A, Abdel-Hafez MAM (2008) Reproductive performance traits as affected by heat stress and its alleviation in sheep - a review. Tropical and Subtropical Agroecosystems 8, 209-34

Marai IFM, Habeeb AAM (1998) Adaptation of Bos taurus cattle under hot climate conditions. Ann Arid Zone 37 (3), 253-81

Marai IFM, Habeeb AAM, Farghaly HM (1999) Productive, physiological and biochemical changes in imported and locally born Friesian and Holstein lactating cows under summer conditions of Egypt. Trop Anim Health Prod 31, 233-43

Marai IFM, Habeeb AAM, Gad AE (2007b) Biological functions in young pregnant rabbit does as affected by heat stress and lighting regime under sub-tropical conditions of Egypt. Tropical and Subtropical Agroecosystems 7, 165-76

Marai IFM, El-Darawany AA, Nasr AS, Shehata MA (under publication) Environment discomfort and ability to sustain the performance trait levels of newly imported and their locally born Holstein Friesian cows at first parity under the sub-tropical conditions of Egypt

NRC (1978) The Nutrient Requirements of Dairy Cattle. 5th ed, National Research Council / Subcommittee on Dairy Cattle Nutrition, Washington, DC, USA

Payne WJA (1970) Cattle production in the tropics, (Tropical agriculture series), Longman, UK

SAS (1993) SAS/STAT Guide for Personal Computers. SAS Inst Inc, Cary, NC, USA

Snedecor GW, Cockran WG (1994) Statistical Methods. 7th ed, lowa State University Press, Ames, USA

Tawfik ES, Mohsen K, Salem AY, El-Awady HG (2000) Study on Friesian raised in Egypt and Germany. 1. Estimate of non-genetic effects and genetic parameters. Arch Tierz 43, 101-14

Tekerly M, Kocak S (2009) Relationship between production and fertility traits in first lactation and life time performances of Holstein under subtropical condition. Arch Tierz 52, 364-70

Received 20 September 2009, accepted 17 July 2010.

Corresponding author:

IBRAHIM FAYEZ MAHMOUD MARAI

email: ifmmarai@yahoo.co.uk

Department of Animal Production, Faculty of Agriculture, Zagazig University, Zagazig, Egypt 